Int. J. Agril. Res. Innov. Tech. 10(2): 35-37, December 2020 Available online at https://ijarit.webs.com DOI: https://doi.org/10.3329/ijarit.v10i2.51574 https://www.banglajol.info/index.php/IJARIT

\title{
Evaluation of black cumin genotypes for yield and yield related parameters in bale mid altitude, southeastern Ethiopia
}

\author{
G. Asefa and M. Beriso \\ Received 11 June 2020, Revised 29 September 2020, Accepted 24 December 2020, Published online 31 December 2020
}

A B S T R A C T

Fourteen black cumin genotypes were evaluated against standard checks for two consecutive years during 2018 to 2019 at Sinana, Goro and Gindhir to investigate high yielder and stable black cumin varieties. The mean total seed yield of genotypes across environment ranged from 24.54 to 16.07 Qt ha-1. The highest total seed yield was recorded from genotypes 242826-2 followed by 242826-2 (24.54 and 23.32 Qt $^{-1} \mathrm{~h}^{-1}$ ) while the lowest total seed yield was obtained from local checks. These two genotypes have yield advantage of 22.41 and 14.96\% over standard check Derbera. Based on their performance across location over standard checks these two genotypes will be promoted for variety verification for Bale mid altitude and similar agro ecologies.

Keywords: Black cumin, Genotype, Oleoresin content.

Department of Horticulture and Seed Spice, Sinana Agricultural Research Center, P.O. Box 208, Bale Robe, Ethiopia.

*Corresponding author's email: fenetgeach@gmail.com (G. Asefa)

Cite this article as: Asefa, G. and Beriso, M. 2020. Evaluation of black cumin genotypes for yield and yield related parameters in bale mid altitude, southeastern Ethiopia. Int. J. Agril. Res. Innov. Tech. 10(2): 35-37. https://doi.org/10.3329/ijarit.v10i2.51574

\section{Introduction}

Black cumin, Nigella sativa L. is an annual herbaceous plant belonging to the family Ranunculacea (Hammo, 2008). Its seed constituents have unique chemical properties with more than one hundred different chemical components (Bardideh et al., 2013). The Ethiopian variety of black cumin seed accumulate up to 50\% thymol, a monocyclic phenolic compound which make valuable source for healthcare (Merga Jibat et al., 2018). Black cumin is used principally to flavor food, either as whole grain, in powdered form or as an oleoresin extract (Black et al., 2006). Within Ethiopia, its main use is as a spice, which is typically ground and mixed with other spices. There is also some use in traditional medicine (Aminpour and Karimi 2004). The vast majority of Ethiopia's black cumin exports go to Arabic countries, which together with other predominantly Muslim countries.

Moreover, the production and land coverage of black cumin in Bale mid altitude have been increasing while the productivity is still less than national average 1.7 ton per hectors (Girma et al., 2008). In Bale mid altitude, highland seed spices viz., black cumin, fenugreek and coriander are produced widely. About 42,00o ha of black cumin produced per year both in "Gena" and "Bona" cropping season in Bale districts (Goro, Ginnir, Golocha and some part of Sawwena and Sinana. Due to increased demand of black cumin seed for local consumption and other importance, such as oil and oleoresin for medicinal purposes, its export market, its potentiality in crop diversification, income generation and its importance to reduce the risk of crop failure and others made black cumin as a best alternative crop under Bale mid altitudes. But, the yield of black cumin in these areas is not as much as the potential of the crop due to many factors among which lack of high yielder and stable varieties are the majors. Hence, developing an improved variety, after screening of lines/accessions with desirable traits, of these crops is one of the immediate measures to be taken. Accordingly, this activity was initiated to evaluate and identify the genotypes of black cumin that are high yielding and tolerant to major disease in mid attitudes of Bale, southeastern Ethiopia. 


\section{Materials and Methods}

Fourteen black cumin genotypes were evaluated against standard (Derbera, Dirshaye and Eden) and local checks for two consecutive years during 2018 to 2019 under rain-fed conditions at Sinana, Goro and Gindhir. The areas possess a bimodal rainfall type. This bimodal rainfall system has created favorable condition to produce crops twice annually or double crop production season.

The experimental trial was laid out in a Randomized Complete Block Design (RCBD) with three replications. Each variety was planted in four rows at spacing of $30 \mathrm{~cm}$ between rows 2.4 $\mathrm{m}^{2}$. Fertilizer application was made as per the national recommendation made for the crop which is $100 \mathrm{~kg} \mathrm{ha}^{-1}$ and the whole rate was applied at planting. Mean yield and disease score of genotypes will be computed using GENSTAT $15^{\text {th }}$ edition.

\section{Results and Discussion}

The mean total seed yield of genotypes across environment ranged from 24.54 to 16.07 $\mathrm{Qt} \mathrm{ha}^{-1}$. The highest total seed yield was recorded from genotypes 242826-2 (24.54 Qt ha-1) followed by 242826-2 (23.32 Qt ha-1) while the lowest total seed yield was obtained from local checks. These two genotypes have yield advantage of 22.41 and
14.96\% over standard check Derbera. The mean for capsule number per plant, biomass and primary branch was ranged from 10.72 to 6.96 , 63.74 to 39.79 and 4.67 to 3.33 (Table 2). The highest number of capsule per plant (10.72), biomass (63.94 t ha-1) and primary branch (4.67) were recorded from genotypes 242826-2 followed by genotype $205167-2$. This implies agronomic parameters were contributed directly or indirectly to total seed yield for black cumin. Similar findings were reported previously by Girma et al. (2016) and Fufa (2016) who indicated black cumin seed yield is positively correlated with plant height, number of capsules per plant, number of primary branches per plant, and number of seeds per capsule. Days to maturity and days to flowering were ranged from 144.83 to 128.00 and 90.00 to 80.00 , respectively. Genotype 242826-2 has two weeks early maturing which is used for scape forcing maturity due to shortage of rainfall mostly occurs in the study area.

The highest means of total seed yield was recorded from Ginnir (23.57 Qt ha' ${ }^{-1}$ ) followed by Sinana (21.77 Qt ha-1). This may be due to potential of the district for black cumin production than both sampled environment.

Table 1. Means of seed yield (Qt ha-1) of 14 black cumin genotypes across location and years.

\begin{tabular}{|l|c|c|c|c|c|c|c|}
\hline & Ginnir & \multicolumn{3}{|c}{ Goro } & \multicolumn{3}{c|}{ Sinana } \\
\hline Genotype & 2016 & 2017 & 2016 & 2017 & 2016 & 2017 & $\begin{array}{c}\text { Grand } \\
\text { Means }\end{array}$ \\
\hline $205167-2$ & & & & & & & \\
\hline $207540-2$ & 26.55 & 26.60 & 18.60 & 19.35 & 24.05 & 24.80 & 23.32 \\
\hline $208688-1$ & 22.63 & 22.68 & 14.68 & 15.43 & 20.13 & 20.88 & 19.41 \\
\hline $242826-2$ & 24.99 & 24.94 & 17.04 & 17.69 & 22.49 & 23.14 & 21.72 \\
\hline $242842-1$ & 28.46 & 27.13 & 20.51 & 19.88 & 25.96 & $25 \cdot 33$ & 24.54 \\
\hline $90510-2$ & 20.92 & 22.94 & 12.97 & 15.69 & 18.42 & 21.14 & 18.68 \\
\hline $90514-2$ & 24.41 & 24.46 & 16.46 & 17.21 & 21.91 & 22.66 & 21.18 \\
\hline $90516-2$ & 21.66 & 23.57 & 13.71 & 16.32 & 19.16 & 21.77 & 19.36 \\
\hline $90575-2$ & 23.16 & 23.88 & 15.21 & 16.63 & 20.66 & 22.08 & 20.27 \\
\hline $910619-2$ & 23.45 & 23.50 & 15.50 & 16.25 & 20.95 & 21.70 & 20.23 \\
\hline Derbera & 17.78 & 23.28 & 9.83 & 16.03 & 15.28 & 21.48 & 17.28 \\
\hline Dirshaye & 22.48 & 22.81 & 14.53 & 16.39 & 19.98 & 21.01 & 19.53 \\
\hline Edan & 19.62 & 22.00 & 11.67 & 14.75 & 17.12 & 20.20 & 17.56 \\
\hline Local & 21.83 & 21.74 & 13.88 & 14.49 & 19.33 & 19.94 & 18.53 \\
\hline Mean & 18.16 & 20.49 & 10.21 & 13.24 & 15.66 & 18.69 & 16.07 \\
\hline CV & 22.58 & 23.57 & 14.63 & 16.38 & 20.08 & 21.77 & 19.83 \\
\hline LSD & 4.3 & 9.5 & 6.7 & 14.1 & 4.9 & 10.3 & 18.70 \\
\hline & 1.79 & 3.75 & 1.63 & 3.88 & 1.63 & 3.75 & 2.43 \\
\hline
\end{tabular}


Table 2. Summary of mean yield and other agronomic traits on the two promising black cumin genotypes selected as candidate for release and checks in regional variety trial over the six environments.

\begin{tabular}{|c|c|c|c|c|c|c|c|c|}
\hline Genotypes & $\mathrm{DF}$ & DM & $\mathrm{PH}$ & $\mathrm{PB}$ & SB & CPP & BMTH & SY \\
\hline $205167-2$ & 81.58 & 135.50 & 50.90 & 4.44 & 2.17 & 9.22 & 58.89 & 23.32 \\
\hline 207540-2 & 88.25 & 140.17 & 58.90 & $3 \cdot 33$ & 0.61 & 7.17 & 51.48 & 19.41 \\
\hline 208688-1 & 82.58 & 133.50 & 51.23 & $3 \cdot 72$ & 2.61 & 7.17 & 55.14 & 21.72 \\
\hline 242826-2 & 90.92 & 144.83 & 58.90 & 4.61 & 3.44 & 10.72 & 63.94 & 24.54 \\
\hline $242842-1$ & 80.58 & 128.50 & 49.90 & 4.28 & 1.44 & 8.56 & 39.79 & 18.68 \\
\hline $90510-2$ & 89.58 & 133.50 & 55.57 & 4.61 & 1.44 & 8.61 & 43.06 & 21.18 \\
\hline $90514-2$ & 80.58 & 129.50 & 50.23 & 4.67 & 1.78 & 8.56 & 50.33 & 19.36 \\
\hline $90516-2$ & 81.58 & 134.50 & 56.57 & 3.78 & 1.50 & 8.67 & 48.50 & 20.27 \\
\hline $90575^{-2}$ & 86.58 & 143.50 & 57.57 & 4.56 & 1.17 & 8.61 & 49.28 & 20.23 \\
\hline 910619-2 & 86.58 & 138.50 & 58.90 & 4.28 & 0.94 & 7.28 & 44.51 & 17.28 \\
\hline Derbera & 81.58 & 138.50 & 48.57 & 4.17 & 1.72 & 8.94 & 43.17 & 19.53 \\
\hline Dirshaye & 83.58 & 137.50 & 49.23 & 3.72 & 1.50 & 8.78 & 42.55 & 17.56 \\
\hline Edan & 83.58 & 133.50 & 50.90 & 4.22 & 0.56 & 6.94 & 49.94 & 18.53 \\
\hline Local & 84.58 & 133.50 & 49.90 & 4.11 & 2.11 & $7 \cdot 33$ & 43.21 & 16.07 \\
\hline Mean & 84.44 & 136.07 & 53.38 & 4.18 & 1.64 & 8.33 & 48.84 & 19.83 \\
\hline CV & 6.90 & 4.90 & 7.60 & 22.00 & 35.00 & 14.00 & 11.10 & 18.70 \\
\hline LSD & 3.80 & 4.33 & 2.70 & 0.60 & 0.37 & 0.80 & 3.55 & 2.43 \\
\hline
\end{tabular}

Note: $D F=$ days to flower, $D M=$ days to maturity, $P H=$ plant height, $P B=$ primary branches/plant $S B=$ secondary branches/plant, $C P P=C a p s u l e / p l a n t, B M T H=$ biomass mass ton per hectare, and $S Y=$ seed yield Quintal per hectare.

\section{Conclusion and Recommendation}

The yield performance of two genotypes 2428262 and 205167-2 across environment and yield advantage of both genotypes over standard checks were 22.41 and $14.96 \%$, respectively. This suggested that, both genotypes were promoted for variety verification for Bale mid altitudes and similar agro ecologies.

\section{Acknowledgements}

The authors are acknowledged Oromia Agricultural Research Institute and Sinana Agricultural Research Center for financing and facilitate this research work.

\section{References}

Aminpour and Karimi. 2004. Underutilized medicinal spices. Spice India. 17: 5-7.

Bardideh, K., Kahrizi, D. and Ghobadi, M.E. 2013. Character association and path analysis of black cumin (Nigella sativa L.) genotypes under different irrigation regimes. Not. Sci. Biol. 5: 104-108. https://doi.org/10.15835/nsb518968

Black, M., Bewley, J.D. and Halmer, P. 2006. The Encyclopedia of seed science, technology and uses. Wallinoford. CABI, UK. p. 763. https://doi.org/10.1079/9780851997230.0000
Fufa, M. 2016. Correlation studies in yield and some yield components of black cumin (Nigella sativa L.) landraces evaluated at Southeastern Ethiopia. Adv. Crop Sci. Tech. 4(5): 239.

https://doi.org/10.4172/2329-8863.1000239

Girma, H., Digafie, T., Edossa, E., Belay, Y.B. and Weyessa, G. 2008. Spices research achievements, revised edition, Ethiopian Institute of Agricultural Research, Addis Ababa Ethiopia. pp. 7-25.

Girma, H., Habtewold, K. and Haimanot, M. 2016. Spices research achievements, challenges and future prospects in Ethiopia. Acad. Res. J. Agril. Sci. Res. 4(1): 9-17.

Hammo, Y.H. 2008. Effect of high levels of nitrogen and phosphorous fertilizer, pinching, and seed rate on growth and yield components of Nigella sativa L. 1-vegetative growth and seed yield. Mesopotamia $J$. Agric. 36: 1-8.

https://doi.org/10.33899/magrj.2008.26581

Merga Jibat, Wakjira Getachew Ommit A, Habetewold Kifelew and Abukiya Getu. 2018. Survey and identification of black cumin (Nigella Sativa L.) disease in Ethiopia. Int. J. Res. Agric. Forest. 5(11): 3134. 